\title{
GLOKALISASI KURIKULUM PENDIDIKAN AGAMA ISLAM MADRASAH ALIYAH KEAGAMAAN DI ERA REVOLUSI INDUSTRI 4.0
}

\author{
1 Heny Kusmawati, ${ }^{2}$ Anista Ika Surachman \\ ${ }^{1}$ kusmawati.heny@gmail.com , 2anistasurachman@ gmail.com \\ ${ }^{1,2}$ Program Studi Pendidikan Agama Islam, Sekolah Tinggi Agama Islam Pati
}

\begin{abstract}
ABSTRAK
Glokalisasi dimaknai sebagai globalization with local flavor yang mana pada Pendidikan Islam, tidak terlepas dari pengembangan pendidikan lokal melalui pendekatan global value chain dan upgrading produk lulusan pendidikan. Implementasi perubahan yang dilakukan pada globalisasi lebih bertumpu perubahan material yang sebenarnya bertentangan dengan ajaran agama Islam karena masyarakat revolusi 4.0 lebih diwakili oleh kapitalisme dan sosialisme dengan ketergantungan internet. Madrasah Aliyah Keagamaan adalah salah satu lembaga yang mewadahi tentang bagaimana pembentukan siswa dengan kepribadian ISLAMI (Ikhlas-Sabar-Lillah-Amanah-Maunah-Islah) yang memiliki ilmu teknologi dan kualitas yang mampu bersaing dalam globalisasi tanpa meninggalkan budaya daerah. Tujuan penulisan artikel ini adalah mendeskripsikan peluang glokalisasi kurikulum Pendidikan Agama Islam (PAI) Madrasah Aliyah Keagamaan di era revolusi industri 4.0. Metode penelitian adalah studi literature dengan mengumpulkan data-data tertulis dari sumber referensi yang terkait. Hasil tulisan artikel ini memetakan 1) urgensi dan peluang glokalisasi kurikulum PAI Madrasah Aliyah Keagamaan, dan 2) tahapan penyusunan glokalisasi kurikulum PAI Madrasah Aliyah Keagamaan di era revolusi industri 4.0.
\end{abstract}

Kata kunci: glokalisasi, kurikulum PAI, revolusi industri 4.0.

\section{PENDAHULUAN}

Salah satu bentuk menghadapi tantangan revolusi industri 4.0 di bidang pendidikan melalui pengembangan kurikulum. Kurikulum memiliki kedudukan sentral dalam proses pendidikan karena didalamnya terdapat rencana pendidikan yang memberikan pedoman dan pegangan tentang jenis, lingkup, dan urutan isi, serta proses pendidikan. Undang-undang nomor 2 tahun 2003 tentang sistem pendidikan nasional disebutkan bahwa kurikulum adalah seperangkat rencana dan pengaturan mengenai tujuan, isi, dan bahan pelajaran, serta cara yang digunakan sebagai pedoman penyelenggaraan kegiatan pembelajaran untuk mencapai tujuan pendidikan tertentu.

Munculnya era revolusi industri 4.0 salah satunya ditandai dengan pesatnya perkembangan dunia digital, yang memudahkan setiap lapisan masyarkat untuk beriteraksi atau 
terhubung satu dengan yang lainnya. Di bidang pendidikan ditandai dengan munculanya adanya pemanfaatan dibidang teknologi informasi dalam kegiatan pembelajaran baik yang bersifat hybrid learning ataupun blended learning.

Perkembangan era digital telah merasuk ke berbagai kawasan negaranegara di dunia. Semua saling terhubung satu sama lain, seakan tiada batas yang menjadi sekat (borderless). Segala informasi terbuka yang ada dalam suatu kawasan dapat diketahui seketika juga oleh penduduk diketahui di kawasan lain. Semua itu terjadi karena hadirnya era digital yang telah menggantikan dominasi era konvensional. Era digital sendiri terlahir dari rahim serta pesatnya perkembangan era global atau globalisasi (Nata, 2011:10). Perubahan dalam kehidupan manusia sudah dimulai dengan adanya era digital atau disebut juga revolusi industri 4.0. Aktivitas yang mendominasi aktivitas manusia adalah internet dan mulai dari aspek pendidikan, sosial, ekonomi dan lain sebagainya.

Dalam era global keadaan dunia menurut seorang futurolog terkenal,
Alvin Toffler, bergerak memasuki dunia baru yang dikenal dengan istilah The Third Wave (Gelombang Ketiga), yakni gelombang peradaban dengan merambahnya teknologi informasi, komputerisasi, revolusi biologi, teknologi perang dan terorisme, dan lain-lain yang bersifat global (Azra, 2012: 41-42). Di era itulah perkembangan teknologi dan perangkat digital semakin canggih dan terus dikembangkan serta diperbarui. Gelombang peradaban tersebut membuat manusia tidak terlepas dari produk-produk digital. Bahkan semuanya kian terhubung, terbuka dan saling ketergantungan. Meski tetap memiliki wilayah teritorial dan garis pemisah yang jelas secara geografis, namun batas-batas tersebut tak menjadi tirai penghalang untuk berinteraksi, berkomunikasi dan berbagi informasi secara terbuka oleh masyarakat digital.

Gambaran tentang masyarakat digital dapat terlihat dari dinamika perilaku dan kecenderungan peminatan generasi milenial saat berinteraksi dengan dunia internet dalam kaitannya dengan dunia pendidikan. Hakikatnya, dinamika dan arah seluruh perubahan sosial dan pendidikan di era digital 
adalah suatu tingkat kemajuan masyarakat, baik material maupun spiritual (Sud, 2005: 131). Hanya saja, karena adanya perbedaan sudut pandang tentang material dan spiritual dari masing-masing ideologi, kemajuan yang dikehendaki sudah tentu tidak sama. Masyarakat maju sekarang lebih diwakili oleh kapitalisme dan sosialisme. Dalam implementasi perubahan yang dilakukan di era digital lebih bertumpu perubahan material, sesuatu yang sebenarnya bertentangan dengan ajaran agama Islam.

Auguste Comte, seorang filosof barat, pernah melakukan analisis terhadap perkembangan intelektual manusia dengan konsep Law of Three Stages. Teori ini mengatakan bahwa tahap permulaan intelektual manusia adalah tahap berfikir teosofik, kemudian tahap metafisik, dan meningkat ketahap berpikir positif. Melalui pengkategorian tersebut, Auguste Comte mengatakan jika manusia atau masyarakat khususnya siswa masih saja memeluk agama artinya tingkat berpikirnya bermain pada teosofik dan metafisik itu sama artinya dengan masyarakat purba atau primitif yang tingkat intelektualnya masih rendah (Sud, 2005: 131-132).
Menurut Comte, tingkat intelektual yang paling maju adalah tahap berpikir positif. Resep Comte tersebut menjadi dominasi masyarakat khususnya siswa saat ini, terutama anak muda. Maka, tidak heran jika kemudian anak muda sekarang lebih menomerduakan agama.

Melihat realitas dan tantangan di atas, maka perlu adanya glokalisasi dalam pengembangan kurikulum. Glokalisasi atau Glocalization merupakan perpaduan antara istilah globalisasi dan lokalisa dimana glokalisasi merupakan sesuatu yang global di interpretasikan dengan nilai-nilai lokal. Glokalisasi muncul sebagai efek dari globalisasi. Nilai-nilai global yang biasanya berasal dari budaya barat dapat dengan mudah diterima dengan mudah oleh masyarakat sebagai dampak negatif globalisasi. Serta terjadinya perubahan gaya hidup remaja dan mulai memudarnya nilai religius serta kearifan lokal budaya bangsa, membuat perlu adanya penyisipan nilai-nilai budaya lokal, khususnya dalam pendidikan. Hal ini ditujukan agar generasi muda siap menyongsong revolusi industri 4.0 tanpa meninggalkan karakter budaya bangsa sendiri.

Madrasah sebagai lembaga pendidikan yang berciri khas nilai-nilai religius keislaman, ternyata banyak 
menarik perhatian, terutama para pemerhati pendidikan. Banyaknya jumlah madrasah yang tersebar, membuat madrasah mampu bersaing dengan sekolah umum lainnya. Madrasah sebagai lembaga pendidikan keagamaan telah memikat masyarakat sabagai salah satu alternatif dalam menyekolahkan anak. Selain pengetahuan umum, madrasah juga lebih difokuskan untuk mendalami agama Islam. Untuk menampung keinginan sebagian masyarakat yang menghendaki pendidikan keagamaan, madrasah melakukan diversifikasi program, salah satunya adalah Madrasah Keagamaan pada jenjang Aliyah.

Madrasah Aliyah merupakan jenjang pendidikan setingkat SMA. Oleh sebab itu, maka isi pengetahuan umumnya harus sesuai dengan lulusan ketrampilan kelompoknya. Salah satu sentral penyelenggaraan pendidikan yaitu kurikulum. Kurikulum pada madrasah tentunya berbeda dengan sekolah umum. Kurikulum yang dikembangkan selain menyangkut pada pengetahuan umum, tetapi juga pada pengembangan ajaran agama islam. Sesuai dengan Anwar (2018: 78) menyebutkan bahwa "The development of curriculum that should be noticed generally is the management of Madrasah curriculum, Madrasah Curriculum has uniqueness with its Islamic education, but it should be thought about how to level the curriculum which becomes guidance for all schools within the group of general school".

Kurikulum pendidikan Islam adalah salah satu kunci dalam pembentukan akhlak peserta didik. Seperti diketahui, tujuan dari kurikulum pendidikan Islam menitik beratkan kepada pemanfaatan hidup manusia tidak hanya didunia tetapi juga di akhirat (Kusmawati, 2016: 1). Nilainilai keagamaan yang harus ditanamkan kepada peserta didik didasarkan kepada sumber utama ajaran Islâm yaitu AlQur'an dan Hadis. Rumusan mengenai kurikulum pendidikan Islam termuat dalam pelaksanaan madrasah.

Program Kagamaan di Madrasah Aliyah merupakan program tambahan pelajaran keagamaan dalam bentuk pendalaman minat keagamaan yang diberikan kepada peserta didik yang mengambil peminatan keagamaan. Oleh karena itu, Madrasah Aliyah 
penyelenggara program keagamaan ini menggunakan struktur kurikulum yang berlaku di Madrasah Aliyah pada umumnya dengan tambahan pendalaman minat keagamaan. Program keagamaan yang diselenggarakan di Madrasah Aliyah masuk dalam beban belajar/struktur kurikulum Madrasah Aliyah pada mata pelajaran keagamaan dan untuk Madrasah Aliyah Penyelenggara Program Keagamaan ditambah dengan materi pendalaman minat keagamaan.

\section{Madrasah Aliyah Keagamaan dapat disebut sebagai salah satu lembaga yang mewadahi tentang bagaimana pembentukan siswa dengan} kepribadian ISLAMI (Ikhlas, Sabar, Lillah, Amanah, Maunah, dan Islah) yang memiliki ilmu teknologi dan kualitas yang mampu bersaing dalam globalisasi tanpa meninggalkan budaya daerah. Rincian mata pelajaran dalam kuriukulum pendidikan Islam, tidak terlepas dari pengembangan glokalisasi atau disebut sebagai globalization with local flavour atau penggabungan pendidikan berbasis lokal dan global value chain. Hal ini dimaksudkan untuk upgrading produk lulusan Pendidikan
Agama Islam yang mampu bersaing dan bertahan di era globalisasi.

Berdasarkan pemaparan tersebut maka tulisan ini difokuskan pada Glokalisasi Kurikulum Madrasah Aliyah Keagamaan di Era Revolusi Industri 4.0. Adapun tujuan penulisan ini yaitu 1) mendeskripsikan urgensi urgensi dan peluang glokalisasi kurikulum PAI Madrasah Aliyah Keagamaan, dan 2) tahapan penyusunan glokalisasi kurikulum PAI Madrasah Aliyah Keagamaan di era revolusi industri 4.0. Manfaat dari studi ini diharapkan dapat dijadikan sebagai acuan dalam pengembangan kurikulum pada lembaga pendidikan islam, khususnya madrasah dalam menghadapi tantangan revolusi industri 4.0.

Penelitian sebelumnya terkait dengan kurikulum madrasah diantaranya penelitian oleh Zulfa \& Pardjono (2013) tentang Manajemen Kurikulum Madrasah Aliyah Program Keagamaan Man 1 Surakarta. Hasil penelitian menunjukkan bahwa menunjukkan bahwa perencanaan kurikulum dilaku-kan melalui workshop berpedoman pada kurikulum nasional, pengembangan keunggulan lokal, dan adaptasi sistem pondok pesantren. 
Selanjutnya penelitian tentang glokalisasi kurikulum dari Nur Hasanah (2018) yang berjudul Glokalisasi Kurikulum Cambridge di Sekolah Dasar Berbasis Islam siswa. Hasil penelitan menunjukkan bahwa adanya adaptasi yang dilakukan oleh sekolah dasar berbasis agama Islam (SDI) yakni Mumtaza Islamic School dan Madrasah Ibtidaiyah (MI) Negeri 1 Ciputat dalam mengadopsi kurikulum internasional khusunya pada metode pembelajaran dalam implementasi kurikulum cambridge.

Berdasarkan pemaparan mengenai kajian studi dengan penelitian terdahulu menunjukkan adanya perbedaan. Perbedaan tersebut yaitu terletak pada objek yang diteliti. Studi ini peneliti mengambil tema yang terbaru terkait revolusi industri 4.0, yaitu tentang glokalisasi kurikulum Madrasah Aliyah Keagamaan.

\section{METODE PENELITIAN}

Penelitian ini dilakukan dengan menggunakan pendekatan kualitaif yang bersifat studi literature. Teknik pengumpulan data yang dilakukan dengan menggunakan dokumen berupa buku literature, jurnal dan hasil penelitian sebelumnya. Teknik analisis data yang digunakan yaitu deskriptif kualitatif dengan menelaah buku literature dan jurnal penelitian sebelumnya yang dapat memberikan gambaran terkait glokalisasi kurikulum Madrasah Aliyah Keagamaan secara general maupun secara spesifik terkait revolusi industri 4.0. Hasil dari berbagai telaah literatur ini akan digunakan untuk mengidentifikasi tentang urgensi dan peluang serta tahap penyusunan glokalisasi kurikulum madrasah keagamaan di era revolusi industri 4.0.

\section{HASIL DAN PEMBAHASAN}

\section{Hasil Penelitian}

Hasil studi ini akan membahsa dua poin utama yaitu Urgensi dan Peluang serta tahapan penyusunan Glokalisasi Kurikulum Madrasah Keagamaan di Era Revolusi Industri 4.0 Urgensi dan Peluang Glokalisasi Kurikulum Madrasah Keagamaan Di

\section{Era Revolusi Industri 4.0}

1. Disrupsi Teknologi

Munculnya teknologi diera digital mengakibatkan perubahan luar biasa di semua disiplin ilmu tak terkecuali Madrasah Aliyah Keagamaan (MAK). Era digital telah 
memberikan teknologi berbasis cyber physical system, gabungan antara domain digital, fisik, dan biologi. MAK harus menyadari urgennya ketersediaan infrastruktur teknologi digital guna memudahkan kegiatan pendidikan. Salah satu kendala yang sering dialami dalam kegiatan pendidikan, pembelajaran, dan administrasi berkaitan dengan tidak atau kurang tersedianya infrastruktur. Inilah yang harusnya dibenahi agar kedepannya pendidikan Islam mampu berbicara lebih baik, memudahkan iswa memperoleh informasi terbaru. Selain itu, siswa Islam harus mampu menjadi lulusan yang memahami teknologi agar mampu berdakwah di dunia internet. Misalnya, membuat konten youtube berisi kajian keislaman dengan narasumber siswa MAK itu sendiri.

Siswa MAK harus meningkatkan kemampuan dalam bidang teknologi, agar Islam dan generasi penerus tidak hancur dengan serangan budaya barat. Apalagi, dunia ini sedang digenggam oleh kaum yahudi yang tanpa diketahui akan menghancurkan Islam secara perlahan melalui degrasi moral generasi qur'ani. Sudah barang tentu, inilah adalah tanggung jawab bersama siswa Islam menjadi pionir dalam cybersecurity dunia agar Islam dan pendidikannya tidak terjajah oleh kaum yahudi yang memasungkan masyarakat dunia di era Revolusi 4.0.

2. Kesesuaian Lulusan dan Dunia Kerja Relevansi pendidikan dan pekerjaan merupakan tolok ukur kualitas lulusan dalam menjawab tantangan pekerjaan yang tersedia. Lulusan yang tersedia apakah sudah mampu memiliki kompetensi/skill yang sesuai profesinya atau ataukah lulusan hanya sekedar memiliki sebuah gelar tanpa memiliki kompetensi/skill sehingga pada akhirnya profesi yang diambil tidak linier dengan jurusannya karennya minimnya kompetensi/skill.

Tantangan ini harus dijawab dengan penyusunan kurikulum dimana, siswa memiliki kesempatan menjadi pribadi yang memiliki number one skill dalam dunia pendidikan dan second skill yakni kewirausahaan sesuai dengan jurusan keagamaan. Menurut Trilling dan Fadel dalam Samani \& Hariyanto (2017: 38) menjelaskan bahwa ada 
empat kurikulum wajib abad-21 yang sangat diperlukan bagi siswa yaitu kesadaran global (global awareness), melek finansial, ekonomi, bisnis dan kewirausahaan (literacy awareness), kesadaran sebagai warga bangsa (civic awareness) dan kesadaran terhadap kesehatan dan kesejahteraan (health and wellness awareness).

Linieritas lulusan dan pekerjaan masih menjadi perbincangan yang hangat dan menjadi permasalahan yang krusial yang terjadi di era digital. Dikotomi Pendidikan Agama Islam dengan pendidikan umum lainnya menempatkan MAK berada pada polemik yang berkepanjangan, dimana, area kerja lulusan MAK diklasifikasikan secara detail sementara kompetensi lulusan tidak berkompeten dalam bidang agama Islam. Ilmu yang hanya dipermukaan memposisiskan siswa Islam harus mampu menambah kemampuannya dalam pembelajaran.

Diselenggarakannya intrakurikuler seperti ondi (orientasi nilai dasar Islam, rusunawa atau rumah susun siswa dimana sikap toleransi, etika, dan pelatihan skill generasi qur'ani diberikan, LKID atau latihan kepemimpinan Islam dasar, dakwatuna atau ibadah praktis dalam kuliah kerja nyata, dan pesantrenisasi bahasa arab serta bahasa inggris sebagai bekal komunikasi berbahasa yang disisipi nilai-nilai keagaaman Islam). Hal ini diperlukan, untuk menambah kemampuan siswa Islam agar mampu berkompetensi diprofesi yang sesuai dengan program agama Islam dan menjadi pendakwah sejuta umat.

3. Literasi Manusia

Madrasah Aliyah Keagamaan perlu mencari metode untuk mengembangkan kapasititas kognitif siswa higher order mental skills, berpikir kritis dan sistemik. Hal tersebut dapat ditempuh dengan beberapa indikator diantaranya adalah sebagai berikut ini.

1) Ketrampilan

Trilling dan Fadel menyebutkan ada tiga ketrampilan yang diperlukan abad-21, yiatu kecakapan belajar dan inovasi yang meliputi berfikir kritis dan pemecahan masalah, komunikasi dan kolaborasi, serta kreativitas dan inovasi, kecakapan melek 
digital yang meliputi, melek informasi, melek media dan melek teknologi iformasi (ICT) dan yang ketiga kecakapan hidup dan kecakapan karier (Sumani \& Haryanto, 2017: 37).

a) Kepemimpinan (leadership)

Pemimpin adalah orang yang memimpin. Sebagai pemimpin harus memilki keunggulan kompetitif atau keunggulan komparatif di dalam kelompoknya. Sifat pemimpin dalam Islam harus mengacu kepada sifat rasul, shidiq (benar), amanah (dapat dipercaya), tablig (menyampaikan), dan fathonah (pandai).

b) Bekerja dalam tim (Team work) Kerja sama terkadang menjadi sebuah kegiatan yang masih banyak dihindari oleh beberapa orang di lingkungan pekerjaan maupun pendidikan. Namun, orang-orang tersebut masih mempertahankan sikap seperti itu. Padahal, banyak sekali keuntungan yang dapat diterima dari bekerja sama dalam satu tim, baik untuk diri seseorang dan juga organisasi. Tidak hanya menawarkan kesempatan yang luar biasa untuk perkembangan profesionalitas, tetapi kerjasama tim juga berarti membuat pekerjaan terasa lebih ringan dan mudah.

Ketika bekerja dalam tim harus mencapai tujuan secara bersama. Semua proses pekerjaan yang anda kerjakan pun akan menjadi lebih efisien karena pekerjaan akan selesai secara bersamaan sesuai dengan kemampuan masing-masing. Tidak hanya itu, bekerja dalam tim juga dapat memudahkan anda untuk menyelesaikan pekerjaan yang menumpuk lebih cepat karena saling berbagi tanggung jawab dengan lainnya. Dari sudut pandang manajemen, meningkatkan kerja sama tim dalam lingkungan kerja juga akan membantu perusahaan atau departemen anda untuk mengambil pekerjaan tambahan dan akhirnya mendapatkan keuntungan atau bonus tanpa harus menambah 
Salah satu keuntungan terbesar yang akan anda terima setelah melakukan kerja sama tim adalah siswa Islam akan mendapatkan inspirasi serta ide-ide baru dari diskusi bersama tim. Seperti yang telah disebutkan di atas, kerja sama tim sangat penting dilakukan untuk mendapatkan pengalaman belajar dari berbagai lata belakang pendidikan yang lebih penting adalah melatih kemampaun berkomunikasi seperti diskusi terbuka sehingga setiap anggota tim akan mendapatkan informasi yang memadai berkaitan dengan proyek tersebut. Selain itu, kolaborasi di dalam tim dapat membawa para anggota tim berkumpul bersama dan bekerja untuk mencapai tujuan yang sama melalui berbagai perspektif untuk memberikan suatu solusi dengan cara atau ide yang beragam.

Kaitannya dengan
program pendidikan agama
Islam, siswa Islam harus dilatih
untuk memiliki team work

seperti penugasan yang dilakukan secara continue bagi individu maupun kelompok.

c) Enterpreneurship atau termasuk social enterpreunership harus memiliki kapasitas dasar yang dimiliki oleh semua siswa

Siswa adalah agen of change yang akan merubah dunia. Salah satu komponen terbesar didunia selain pendidikan adalah kewirausahaan. Glokalisasi Kurikulum harus mampu mewadahi siswa untuk mengembangkan jiwa kewirausahaan sebagai second skill yang akan diperlukan untuk menunjang kehidupan siswa dimasa mendatang.

Mata pelajaran kewirausahaan akan membantu siswa lebih mandiri dan mampu menghadapi era glokalisasi yang sekarang menjadi fenomena baru yang terjadi di lingkungan negara berkembang maupun negara maju. Globalisasi dan kearifan lokal harus disenergikan untuk mendapatkan sebuah 
kewirausaahaan yang mampu membangkitkan kearifan lokal diwilayah tersebut. Contoh lainnya adalah pelatihan kaligrafi yang dilakukan siswa PKL (Pelatihan Kerja Lapangan) sehingga menghasilkan mayarakat yang mampu memiliki kebebasan finacial dengan cara mengkomersilkan kaligrafi.

Tilaar menyebutkan tantangan utama pendidikan adalah kualitas (Daulay: 2012: 170), dimana lulusan menjadi salah satu alat evaluasi keberhasilan kurikulum sesuai eranya. Dibutuhkan formula dan strategi menyeluruh dalam melihat peluang serta tantangan besar di era serba digital saat ini. Glokalisasi kurikulum MAK tidak boleh ditunda apalagi mengabaikan hal tersebut, karena secara perlahan atau secepatnya, perubahan zaman akan terus terjadi dan perkembangan revolusi industri 4.0 akan berlangsung pesat, yang berpengaruh besar bagi peradaban dunia.
Tahap Penyusunan Glokalisasi Kurikulum Madrasah Aliyah Keagamaan di Era Revolusi Industri 4.0

Untuk menghadapi revolusi industri 4.0, Madrasah Aliyah Keagamaan sebagai institusi pendidikan Islam Indonesia yang bertujuan mencetak kader pendakwah membutuhkan penambahan nilai seperti teknologi modern, globalisasi, pluralisme, multikulturalisme, dan inklusifisme. Selain itu, Inovasi dan modernisasi Madrasah Aliyah Keagamaan harus dilakukan dengan memperimbangkan ilmu umum dan isu modern. Implementasi kurikulum yang disertai inovasi global dan lokal disebut dengan glokalisasi kurikulum

Glokalisasi kurikulum perlu dilakukan untuk mendapatkan pembaharuan keilmuan yang dibutuhkan output madrasah aliyah keagamaan dalam menghadapi kompetitor yang ada di era revolusi industri 4.0. Dengan demikian diperlukan tahapan penyusunan glokalisasi kurikulum MAK seperti dibawah ini.

1. Kepala dan wakil kurikulum disertai guru membuat kerangka glokalisasi 
dengan melestarikan kearifan lokal dan kekayaan kebudayaan dalam kegiatan pembelajaran serta memberikan wawasan dan ketrampilan global kepada para siswa. Patel \& Lynch (2013: 223230) menyatakan bahwa glokalisasi dalam konteks kurikulum pendidikan Islam mencakup keadilan, keragaman, inklusifitas, dan kemitraan glokal dan dijelaskan dalam empat dimensi dalam kerangka Global Engagement Dimensions (GED) yaitu (intelektual, Emosi, Aksi, dan Moralitas). Keempat dimensi tersebut merupakan komponen penting dari kerangka kerja glokalisasi pendidikan. Masingmasing dari empat dimensi memiliki peranan signifikan untuk memastikan bahwa hasil yang ditindaklanjuti adalah adil, inklusif, dan beragam. Pemangku kepentingan merupakan pendidik dalam wacana pembelajaran yang berbasis glokalisasi diharapkan untuk memahami dan menunjukkan kemampuan diempat dimensi yang memadukan keberhasilan. Adapun penjelasannya terdapat dalam Nisa, (2018: 113-114):

a. Intellect; $a \mathrm{kal}$ adalah dimensi kunci, karena intelektual menurut individu dan kelompok untuk mendemons-trasikan pengetahuan, pendidikan, dan kebijaksanaan sebagai santri yang menanggapi peristiwaperistiwa glokal dengan kompleksitas lingkungan glokal. Dalam hal ini menurut penulis, pemangku kebijakan wajib memberikan pengetahuan terlebih dulu terkait program berwawasan lokal dan global agar sebelum rancangan dilaksanakan tidak terjadi kesalah pahaman. Dapat dengan cara mengadopsi matapelajaran seperti bahasa indonesia, matematika, PKN, bahasa inggris, sejarah indonesia, dan bahasa arab.

b. Emotion. Emosi adalah dimensi penting lainnya yang harus dikelola dengan hati-hati. Diantara berbagai emosi yang sesuai, santri akan menunjukkan kepekaan, pemaha-man, intuisi, dan belas 
kasihan. Dalam menanggapi situasi glokal, siswa menunjukkan pemahaman tentang situasi. Menurut penulis dimensi emosi dipengaruhi mata pelajaran tafsir-ilmu tafsir, Fikih-ushul fiqh, hadisilmu hadis, dan ilmu kalam. Beberapa ilmu tersebut akan mempengaruhi kepercayaan siswa Islam, sikap optimis, pesimis, rasa syukur dan lain sebagainya.

c. Action; kerangka kerja keterlibatan glokal adalah kerangka kerja aksi yang menuntut siswa untuk bertindak. Tujuannya adalah untuk menyelesaikan, membangun, dan mengubah situasi demi keuntungan bersama dari semua pemangku kepentingan. Tindakan mengacu pada komitmen dan tanggung jawab untuk membawa perubahan dalam kualitas hidup bagi komunitas. Menjadikan penulis memahami bahwa kelompok mata pelajaran B seperti kewirausahaan, seni budaya, dan olahraga merupakan salah satu kerja aksi siswa untuk bertindak dan mencoba peluang sehingga mampu mandiri ketika sudah menjadi lulusan

d. Morality; dimensi penting kunci lainnya adalah moralitas. Siswa membutuhkan standar moralitas yang tinggi sehingga semua masalah yang dibawa kedalam dialog glokal dapat dinilai berdasarkan etika. Sangat penting bahwa harus ada integrasi antara kebijakan dan keadilan. Sesuai pemahaman penulis, dengan realita yang ada dalam kurikulum 2013 ataupun kurikulum nasional, selalu disisipkan unsur moral dalam susunan struktur kurikulum dan didalam madrasah aliyah kejuruan morality didapatkan dari materi pelajaran akidah akhlak, fikih, qur'an hadist, dan sejarah kebudayaan Islam. Dalam glokalisasi kurikulum, moral ini harus mampu memperluas pengetahuan siswa sehingga tidak berfikiran yang monoton terhadap Islam di era revolusi industri 4.0, dapat menjadi output moral Islam 
kontemporer yang mampu berbaur dengan pergaulan yang ada dimasyarakat.

2. Pemenuhan glokalisasi kurikulum dimulai dari visi dan misi sebuah lembaga, kualitas guru, bangunan sekolah, sarana prasarana dan izin pengembangan glokalisasi kurikulum. penunjang pelaksanaan glokalisasi kurikulum.

Sub komponen implementasi glokalisasi kurikulum MAK dapat dilihat pada tabel 1 di bawah ini.

Tabel 1. Sub Komponen Glokalisasi Kurikulum PAI MAK di Era Revolusi Industri 4.0

\begin{tabular}{|c|c|c|c|c|}
\hline Metode & $\begin{array}{l}\text { Proses } \\
\text { kegiatan }\end{array}$ & $\begin{array}{c}\text { Konten } \\
\text { Lokal }\end{array}$ & $\begin{array}{l}\text { Berorientasi } \\
\text { produk global } \\
\text { terhadap lokal }\end{array}$ & Penun-jang \\
\hline 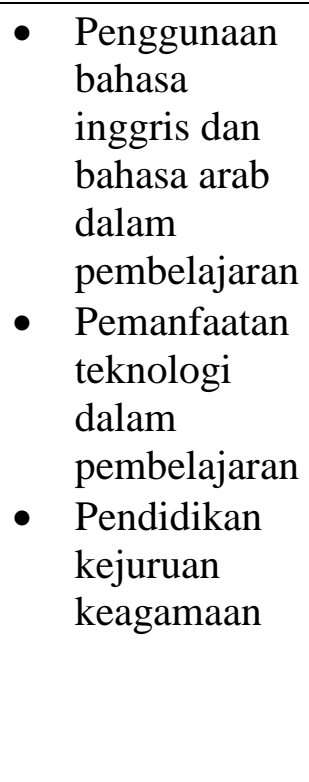 & 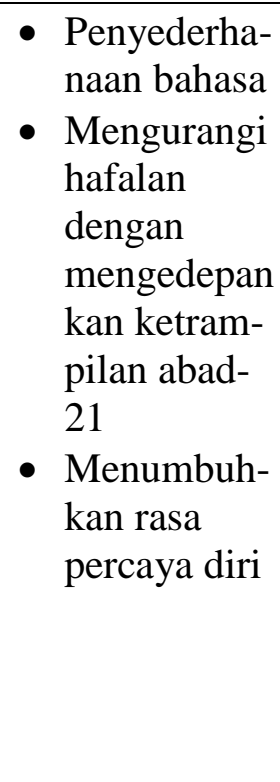 & $\begin{array}{l}\text { - Menanam } \\
\text { kan nilai } \\
\text { adab } \\
\text { - Membiasa } \\
\text { kan } \\
\text { kegiatan } \\
\text { agamis } \\
\text { - Perubah- } \\
\text { an materi } \\
\text { bahan ajar } \\
\text { - Penggu- } \\
\text { naan } \\
\text { contoh } \\
\text { materi } \\
\text { untuk } \\
\text { konten }\end{array}$ & $\begin{array}{l}\text { - Kurikulum } \\
\text { lokal dan } \\
\text { Pancasila } \\
\text { - Bahasa } \\
\text { pengantar } \\
\text { menggunakan } \\
\text { bahasa Arab } \\
\text { dan Inggris } \\
\text { - Sinkronisasi } \\
\text { program } \\
\text { - Guru } \\
\text { berwawasan } \\
\text { internasional }\end{array}$ & $\begin{array}{l}\text { - Orang tua } \\
\text { - Pendidik } \\
\text { - Peserta } \\
\text { didik } \\
\text { - Lingkung- } \\
\text { an }\end{array}$ \\
\hline
\end{tabular}

3. Penyesuaian metode pembelajaran, proses kegiatan, konten lokal, produk lokal dan global, dan

\section{Diskusi Hasil Penelitian}

Munculnya revolusi industry 4.0 tentunya memberikan dampak pada 
diberbagai bidang, salah satunya di dunia pendidikan. Pendidikan sebagai salah satu pencetak generasi penerus bangsa perlu melakukan pembaruharuan untuk menghasilkan generasi yang mampu bersaing di dunia global. Dalam menghadapi era revolusi industri 4.0, diperlukan pendidikan yang dapat membentuk generasi lulusan yang kreatif, inovatif, dan kompetitif. Untuk menghasilkan hal tersebut salah satunya melaui perencanan kurikulum yang tepat. Kurikulum menjadi sentral dalam proses pendidikan karena di dalamnya terdapat rencana dan pengaturan mengenai tujuan, isi, dan bahan pelajaran, serta cara yang digunakan sebagai pedoman penyelenggaraan kegiatan pembelajaran untuk mencapai tujuan pendidikan tertentu.

Madrasah sebagai salah satu lembaga pendidikan islam harus peka dalam menyesuaikan dengan segala perubahan yang ada di era revolusi industri 4.0. jika tidak ini akan berdampak pada kualitas lulusan yang dihasilkan. Pendidikan Islam di era 4.0 perlu untuk turut mendisrupsi diri jika ingin memperkuat eksistensinya. Mendisrupsi diri berarti menyesuaikan diri dengan kebutuhan dan tuntutan masyarakat serta berorientasi pada masa depan (Priatmoko, 2018: 12).

Hasil penelitian menunjukan bahwasanya pengembangan kurikulum PAI pada Madrasah Aliyah Keagamaan melalui glokalisasi kurikulum sangatlah diperlukan. Hal ini ditujukan untuk mengahadapi tantangan di era revolusi industry 4.0 dimana dibutuhkan kompetensi lulusan yang menguasai ketrampilan abad-21. Urgensi dan peluang glokalisasi kurikulum Madrasah Aliayah Keagamaan di era revolusi industri 4.0 meliputi disrupsi teknologi, kesesuaian lulusan dengan dunia kerja, dan literasi manusia. Perlunya glokalisasi kurikulum dalam pendidikan islam diperlukan untuk mengahdapi tantangan kebutuhan pasar di era revolusi industry 4.0. Priatmoko (2018: 1) dalam peneliti Iulusan pendidikan Islam kini dihadapkan pada tantangan, tuntutan, dan kebutuhan baru yang belum pernah ada sebelumnya sehingga perlu dilakukan pembaruan dan inovasi terhadap sistem, tata kelola, kurikulum, kompetensi sumber daya manusia, sarana dan prasarana, budaya, etos kerja, dan lain-lain.

Tahapan penyusunan glokalisasi kurikulum terdiri dari tiga langkah yaitu 
kepala dan wakil kurikulum disertai guru membuat kerangka glokalisasi dengan melestarikan kearifan lokal dan kekayaan kebudayaan dalam kegiatan pembelajaran serta memberikan wawasan dan ketrampilan global kepada para siswa. Anwar (2018: 78) menyebutkan bahwa "Madrasah should be able to do the developments and managements of curriculum, creating a curriculum development team, do a workshop in developing curriculum, and arranging curriculum with involve various related components, mainly for the teacher". Hal ini jelas bahwasanya madrasah perlu melakukan pengembangan dan pengelolaan kurikulum, dengan membuat tim pengembangan kurikulum, melakukan lokakarya dan mengatur kurikulum dengan melibatkan berbagai komponen terkait, terutama untuk guru.

Kedua adalah pemenuhan glokalisasi kurikulum dimulai dari visi misi sebuah lembaga, kualitas guru, bangunan sekolah, sarana prasana, dan izin pengembangan glokalisasi kurikulum MAK. Kemudian, langkah ketiga dilakukan penyesuaian metode pembelajaran, proses kegiatan, konten lokal, produk lokal dan global, dan penunjang pelaksanaan glokalisasi kurikulum.

Madrasah sebagai salah satu komponen dari lembaga pendidikan Islam, menempati posisi yang unik dan sangat penting bagi masyarakat muslim. Madrasah mengemban tugas yang berat untuk mengintegrasikan ilmu-ilmu agama Islam dengan ilmu-ilmu umum. Haisl penelitian sebelumnya (Chaer, 2016: 182) menyebutkan bahwa "the madrasa has been doing adaptations with the demands of globalization, which became a milestone for the formation of "modern" madrasah with an image in contrast to the madrasa. In this context, the madrasa seems to not see globalization as a thing to be feared but should be faced". Hal ini menujukkan bahwa madrasah perlu melakukan adaptasi terhadap proses pendidikan dalam menyiapkan lulusan madrasah yang berkompeten sesuai dengan kebutuhan abad-21.

Madrasah Aliyah Keagamanan sebagai salah satu lembaga pendiikan yang dibentuk untuk mengantisipasi perkembangan dunia modern dibina untuk menyiapkan lulusan yang memiliki nilai-nilai spiritual sebagai benteng utama pembentukan akhlak/ 
moral siswa, tetapi juga pengetahuan umum dan keterampilan abad-21. Melalui adanya glokalisasi kurikulum PAI pada MAK, selain mempersiapkan lulusan MAK dalam menghadapi revolusi industry 4.0, tetpai juga tetap mempertahankan kearifan lokal budaya bangsa sehingga nilai religius dan kearifan lokab budaya bangsa tetap terjaga.

\section{SIMPULAN}

Berdasarkan uraian diatas, simpulan sebagai berikut.

1. Urgensi dan peluang glokalisasi kurikulum madrasah keagamaan di era revolusi industri 4.0 meliputi disrupsi teknologi, kesesuaian lulusan dengan dunia kerja, dan literasi manusia.

2. Tahap penyusunan glokalisasi kurikulum madrasah keagamaan di era revolusi industri 4.0 diantaranya adalah pertama yang dilakukan adalah kepala dan wakil kurikulum disertai guru membuat kerangka glokalisasi dengan melestarikan kearifan lokal dan kekayaan kebudayaan dalam kegiatan pembelajaran serta memberikan wawasan dan ketrampilan global kepada para siswa. Kedua adalah pemenuhan glokalisasi kurikulum dimulai dari visi misi sebuah lembaga, kualitas guru, bangunan sekolah, sarana prasana, dan izin pengembangan glokalisasi kurikulum MAK. Kemudian, langkah ketiga dilakukan penyesuaian metode pembelajaran, proses kegiatan, konten lokal, produk lokal dan global, dan penunjang pelaksanaan glokalisasi kurikulum.

\section{DAFTAR PUSTAKA}

Anwar, H. 2018. "Implementation Of Education Management Standard In The Guidance of Private Islamic High School". Jurnal Pendidikan Islam. 4 (1): $75-86$. http://journal.uinsgd.ac.id/index .php/jpi/search?subject=Islamic $\%$ 20Education\%20Managemen t diakses pada tanggal 25 Mei 2019

Azyumardi, A., Azyumardi. 2012. Pendidikan Islam: Tradisi dan Modernisasi di Tengah Tantangan Milenium III. Cet ke-1. Jakarta: Kencana.

Chaer, M. T. 2016. Peran Madrasah Dalam Menghadapi Era Globalisasi dan Budaya. MUADDIB. 06 (02): 182-201. http://journal.umpo.ac.id/index. php/muaddib/article/viewFile/4 
61/434 diakses pada 25 Mei 2019 .

Daulay, H.P. 2012. Pendidikan Islam dalam Sistem Pendidikan Nasional di Indonesia. Jakarta: Kencana.

Hasanah, N. 2018. Glokalisasi Kurikulum Cambridge di Sekolah Dasar yang Berbasis Islam. Jakarta. Tesis. (UIN Syarif Hidayatullah: Pascasarjana Pendidikan Islam). http://repository.uinjkt.ac.id/dsp ace/bitstream/123456789/4493 4/1/Nurhasanah_Fix.pdf diakses pada 20 April 2019.

Kusmawati, H. 2016. Implementasi Kurikulum di Penggerak Pembina Generasi Penerus LDII Karanggawang Girikerto Turi Sleman Yogyakarta. Yogyakarta. Tesis. (UII: Magister Studi Islam).

Nata, A. (2011). Kapita Selekta Pendidikan Islam. Cet ke 1. Jakarta: Raja Grafindo Persada

Nisa, K. M. 2018. Globalisasi: Membangun Pendidikan Global Berbasis Kearifan Lokal pada Pondok Modern. Jurnal AnNuha. 5 (1): 101-116. http://moraref.kemenag.go.id/do cuments/article/9807359339239

8433/download diakses pada tanggal 01 Juni 2019.

Priatmoko. 2018. Memperkuat Eksistensi Pendidikan Islam Di

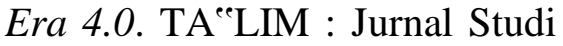
Pendidikan Islam. 1 (2): 1-19. http://ejurnal.unisda.ac.id/index. php/talim/article/view/948 diakses pada 20 April 2019.

Samani, M \& Hariyanto. 2017. Konsep \& Model Pendidikan Karakter. Bandung: PT Remaja Rosdakarya.

Sud, M.A. 2005. Latihan Kepempimpinan Islam Tingkat Dasar (LKID). Yogyakarta: UII Press.

Zulfa, N.C., dan Pardjono. (2013). Manajemen Kurikulum Madrasah Aliyah Program Keagamaan Man 1 Surakarta. Jurnal Akutabilitas Manajemen. $1 \quad$ (2): 219-234 https://journal.uny.ac.id/index.p hp/jamp/article/view/2396 pada tanggal 01 Juni 2019 